\title{
VALUE OF CEREBROSPINAL FLUID ANALYSIS AND SERUM INFLAMMATORY MARKERS FOR DISTINGUISHING BETWEEN VIRAL AND BACTERIAL MENINGITIS IN CHILDREN IN EARLY PHASE OF THE DISEASE
}

M. Šeškutè, E. Tamulevičienè, G. Levinienè

Lithuanian University of Health Sciences (LUHS), Medical Academy, Clinic of Paediatrics, Kaunas, Lithuania

\section{Background}

Regardless of cerebrospinal fluid (CSF) examination there are difficulties distinguishing between bacterial and viral meningitis in early phase of the disease ${ }^{1}$ which leads to unnecessary use of antibiotics.

Methods

We performed a retrospective analysis of 176 cases of children with acute meningitis (defined by a leukocyte count $>5 / \mathrm{mm}^{3}$ in the CSF) who were hospitalized in Kaunas Clinical Hospital from 2008 to 2016 and underwent lumbar puncture during the first 48 hours from the initial symptoms of the disease.

We compared CSF parameters (WBC count, percentage of polymorphonucleocytes (PMNs), protein level) and serum inflammatory markers (CRP and WBC count) as potential predictors of bacterial meningitis.

\section{Results}

The age of included patients ranged from 6 months to 18 years. 17 of them were diagnosed with bacterial meningitis and 159 with viral meningitis.

Of all evaluated markers, CSF WBC count had the highest area under the ROC curve (AUC) of $0.95(\mathrm{p}<0.001)$ with $100 \%$ sensitivity $(52.8 \%$ specificity) when CSF WBC count was $\leq 104$

\begin{tabular}{|c|c|c|c|c|}
\hline Parameters & AUC & Cut off & Sensitivity & Specificity \\
\hline $\begin{array}{c}\text { CSF WBC count } \\
(\text { cells } / \mu \mathrm{l})\end{array}$ & $\begin{array}{c}0.95 \\
(95 \% \text { CI } 0.893- \\
1.0)\end{array}$ & $\begin{array}{c}104 \\
270 \\
1946.5\end{array}$ & $\begin{array}{l}100 \% \\
93.8 \% \\
56.3 \%\end{array}$ & $\begin{array}{c}52.8 \% \\
86.2 \% \\
100 \%\end{array}$ \\
\hline $\begin{array}{c}\text { CSF PMNs } \\
(\%)\end{array}$ & $\begin{array}{c}0.931 \\
(95 \% \text { CI } 0.866- \\
0.996)\end{array}$ & $\begin{array}{l}31.5 \\
82.5 \\
97.5\end{array}$ & $\begin{array}{l}100 \% \\
87.5 \% \\
18.8 \%\end{array}$ & $\begin{array}{c}49 \% \\
94.5 \% \\
100 \%\end{array}$ \\
\hline $\begin{array}{l}\text { CSF protein } \\
(\mathrm{g} / \mathrm{l})\end{array}$ & $\begin{array}{c}0.928 \\
(95 \% \text { CI } 0.874- \\
0.983)\end{array}$ & $\begin{array}{l}0.4 \\
0.6 \\
2.1\end{array}$ & $\begin{array}{l}100 \% \\
82.4 \% \\
35.3 \% \\
\end{array}$ & $\begin{array}{l}68.6 \% \\
84.9 \% \\
100 \% \\
\end{array}$ \\
\hline $\begin{array}{l}\mathrm{CRP} \\
(\mathrm{mg} / \mathrm{l})\end{array}$ & $\begin{array}{c}0.887 \\
(95 \% \text { CI } 0.769- \\
1.0)\end{array}$ & $\begin{array}{c}21.75 \\
68.5\end{array}$ & $\begin{array}{l}82.4 \% \\
64.7 \%\end{array}$ & $\begin{array}{c}90.1 \% \\
100 \%\end{array}$ \\
\hline $\begin{array}{l}\text { Serum WBC } \\
\text { count } \\
(\text { cells/ul) }\end{array}$ & $\begin{array}{c}0.841 \\
(95 \% \text { CI } 0.741- \\
0.941)\end{array}$ & $\begin{array}{l}10450 \\
13050 \\
25850\end{array}$ & $\begin{array}{l}100 \% \\
76.5 \% \\
23.5 \%\end{array}$ & $\begin{array}{l}47.1 \% \\
73.9 \% \\
100 \%\end{array}$ \\
\hline
\end{tabular}

Fig.1. Comparison of CSF parameters and serum inflammatory markers

cells/ul. The other cut off values are shown in Fig. 1. CSF protein $\leq 0.4 \mathrm{~g} / \mathrm{l}$ had $100 \%$ sensitivity ( $68.6 \%$ specificity) for bacterial meningitis.

Serum inflammatory markers (CRP and leukocytosis) were less useful with CRP having an AUC of $0.887(\mathrm{p}<0.001)$ and leukocytosis of $0.841(p<0.001)$.
CRP had $100 \%$ specificity ( $64.7 \%$ sensitivity) when above $68.5 \mathrm{mg} / \mathrm{l}$.

\section{Conclusions}

At early phase of the disease:

- CSF WBC count, CSF protein level, serum CRP and serum WBC were useful biomarkers for distinguishing between bacterial and viral meningitis (based on their AUC values);

- CSF WBC count was the most reliable predictor of bacterial meningitis;

- low CSF WBC count $(\leq 104$ cells/pl) and low CSF protein levels $(\leq 0.4 \mathrm{~g} / \mathrm{l})$ showed low possibility of bacterial meningitis.

Sources:

1. Dashti AS, Alizadeh S, Karimi A, Khalifeh M, and Shoja SA. Diagnostic value of lactate, procalcitonin, ferritin, serum-C-reactive protein, and other biomarkers in bacteria and viral meningitis. Med 